\title{
Penyalahgunaan Surat Keterangan Tidak Mampu Sebagai Syarat Penerima Bantuan Hukum di Riau
}

\author{
Robert Libra*, Wilda Arifalina \\ Fakultas Hukum Universitas Lancang Kuning \\ Jalan Yos Sudarso Km 8, Rumbai, Kota Pekanbaru, Indonesia
}

\begin{abstract}
Abstrak
Tujuan penelitian ini: Pertama, menjelaskan penyalahgunaan surat keterangan tidak mampu sebagai syarat penerima bantuan hukum secara cuma-cuma bagi masyarakat miskin di Provinsi Riau. Kedua, menjelaskan upaya mengatasi penyalahgunaan surat keterangan tidak mampu sebagai syarat penerima bantuan hukum secara cuma-cuma bagi masyarakat miskin di Provinsi Riau. Jenis penelitian ini hukum sosiologis dilakukan dengan cara pendekatan empiris. Berdasarkan hasil penelitian dapat dijelaskan bahwa penyalahgunaan surat keterangan tidak mampu sebagai syarat penerima bantuan hukum secara cuma-cuma bagi masyarakat miskin di Provinsi Riau terjadi dikarenakan penyalahgunaan SKTM. Meskipun Pemerintah Provinsi Riau sudah membuat Peraturan Daerah (Perda) Nomor 3 Tahun 2015 tentang Bantuan Hukum Untuk Masyarakat Miskin, namun Perda tersebut tidak menjelaskan teknis mengurus SKTM. Upaya mengatasi penyalahgunaan surat keterangan tidak mampu sebagai syarat penerima bantuan hukum secara cuma-cuma bagi masyarakat miskin di Provinsi Riau, dapat menggunakan kriteria miskin yang ditentukan Badan Pusat Statistik (BPS). Berdasarkan hasil penelitian ini maka dapat disimpulkan bahwa penyalahgunaan SKTM sebagai syarat penerima bantuan hukum secara cuma-cuma di Provinsi Riau dapat terjadi, karena cara mendapatkan SKTM tidak selektif. Meskipun BPS telah membuat kriteria keluarga miskin, tetapi kriteria tersebut bukan produk hukum sehingga tidak mempunyai kekuatan mengikat untuk ditaati. Upaya mengatasi penyalahgunaan SKTM sebagai syarat penerima bantuan hukum secara cuma-cuma bagi masyarakat miskin di Provinsi Riau harus dilakukan oleh panitia pengawas daerah. Upaya yang dapat dilakukan pengawas daerah mensosialisasikan kriteria miskin BPS tersebut kepada OBH di Provinsi Riau. Kemudian juga mensosialisasikan kriteria tersebut kepada kelurahan/desa di Provinsi Riau sehingga dapat dijadikan pedoman dalam menerbitkan SKTM.
\end{abstract}

\section{Kata Kunci: Surat Keterangan Tidak Mampu, Bantuan Hukum}

\begin{abstract}
The purpose of this study: Firstly, to explain the misuse of certificate of inadequate as requirement of recipient of legal aid free of charge for poor people in Riau Province. Second, explains the effort to overcome the misuse of certificate of incapacity as a condition of recipient of legal aid free of charge for the poor in Riau Province. This research type is sociological law research, done by empirical approach. Based on the results of the research can be explained that the misuse of certificate is not capable as a condition
\end{abstract}

\footnotetext{
*Penulis Korespondensi

E-mail: robertlibra@unilak.ac.id
} 
of recipient of legal aid free of charge for the poor in Riau Province occurred due to misuse SKTM. Although the Provincial Government of Riau has made Regional Regulation (Perda) No. 3 of 2015 on Legal Aid for the Poor, but the law does not explain the technical take care of SKTM. Efforts to overcome the misuse of certificate of inadequate as requirement of recipient of legal aid free of charge for poor people in Riau Province, can use the criterion of poor determined by Central Bureau of Statistics (BPS). Based on the results of this study it can be concluded that SKTM misuse as a condition of recipient of legal aid free of charge in Riau Province can happen, because how to get SKTM not selective. Although BPS has established criteria for poor families, these criteria are not legal products and therefore have no binding power to adhere to. Efforts to overcome SKTM misuse as a condition of recipient of legal aid free of charge for poor people in Riau Province should be done by regional supervisory committee. Efforts that can be done by regional supervisors to disseminate the poor criteria of BPS to OBH in Riau Province. Then also socialize the criteria to the village / village in Riau Province so it can be used as a guide in issuing SKTM

\section{Keywords: Certificate of Not Able, Legal Aid}

\section{Pendahuluan}

Pasal 27 Ayat (1) Undang-Undang Dasar Negara Kesatuan Republik Indonesia Tahun 1945 menegaskan semua warga negara bersamaan kedudukannya di dalam hukum, ketentuan ini lazim dikenal sebagai asas equality before the law atau persamaan dihadapan hukum. Equality before the law memiliki arti bahwa semua orang memiliki hak untuk diperlakukan sama dihadapan hukum. Persamaan perlakuan dihadapan hukum tersebut berlaku bagi setiap orang tanpa membeda-bedakan latar belakang suku, agama, ekonomi atau keturunan, untuk memperoleh keadilan melalui lembaga peradilan. ${ }^{1}$

Asas equality before the law menjadi norma mendasar dalam memberikan perlindungan hak asasi warga negara. Pengakuan dan jaminan terhadap asas equality before the law tidak saja sebatas pengakuan politik saja, akan tetapi lebih mengedepankan tindakan konkrit negara. Jika, asas equality before the law dalam Undang-Undang Dasar sudah dicantumkan maka konsekuensi logis penguasa dan penegak hukum haruslah melaksanakan dan merealisasikan asas tersebut dalam kehidupan bernegara.

Salah satu realisasi dari asas equality before the law sangat diperlukan tindakan konkrit negara dengan membuat undangundang tentang bantuan hukum. Hak atas bantuan hukum sendiri merupakan non derogable rights, sebuah hak yang tidak dapat dikurangi dan tak dapat ditangguhkan dalam kondisi apapun. Oleh karena itu, bantuan hukum merupakan hak asasi semua orang, yang bukan diberikan oleh negara dan bukan belas kasihan dari negara, tetapi juga merupakan tanggung jawab negara dalam mewujudkan equality before the law, acces to justice, dan fair trial.

${ }^{1}$ Eka Susylawati, Implementasi Perkara Prodeo Bagi Masyarakat Miskin di Pengadilan Agama Pamekasan, Jurnal Nuansa, Volume 10, Nomor 1, Januari-Juni 2013, hlm. 125. 
Kitab Undang-Undang Hukum Acara Pidana (KUHAP) menyinggung sedikit tentang bantuan hukum. Namun, hal mengenai bantuan hukum yang diatur dalam KUHAP tersebut hanya mengenai kondisi untuk mendapatkan bantuan hukum. KUHAP tidak memaparkan secara jelas apa yang dimaksud dengan bantuan hukum itu. Karena tidak terdapatnya rumusan pengertian bantuan hukum secara jelas maka perlu dirumuskan pengertian bantuan hukum.

Terdapat dua model (sistem) bantuan hukum, yaitu ajuridicial right (model yuridisindividual) dan awelfare right (model kesejahteraan). Model ajuridicial right menekankan pada sifat individualistis. Sifat individualistis ini maksudnya setiap orang akan selalu mendapat hak untuk memperoleh bantuan hukum. Pada model yuridis individual masih terdapat ciri-ciri pola klasik dari bantuan hukum, artinya permintaan akan bantuan hukum atau perlindungan hukum tergantung pada warga masyarakat yang memerlukannya. Warga masyarakat yang memerlukan bantuan hukum menemui pengacara, dan pengacara akan memperoleh imbalan atas jasa-jasa yang diberikan kepada negara. Jadi, bilamana seseorang tidak mampu maka seseorang itu akan mendapatkan bantuan hukum secara cuma-cuma (prodeo). Awelfare right (model kesejahteraan) mengarahkan bantuan hukum sebagai alat untuk mendapatkan keadilan bagi seluruh rakyat, terutama bagi mereka yang tidak mampu. ${ }^{2}$

Bila melihat kedua model bantuan hukum tersebut maka dapat dijelaskan bahwa bantuan hukum dapat dilihat sebagai suatu hak yang diberikan kepada warga masyarakat untuk melindungi kepentingan-kepentingan individual dan dilain pihak sebagai suatu hak akan kesejahteraan yang menjadi bagian dari kerangka perlindungan sosial yang diberikan suatu negara kesejahteraan. Kedua model bantuan hukum tersebut kemudian menjadi model dasar beberapa pengertian tentang bantuan hukum yang berkembang di dunia barat pada umumnya.

Istilah bantuan hukum merupakan hal baru bagi bangsa Indonesia. Masyarakat baru mengenal dan mendengarnya sekitar tahun 1970-an. Aliran lembaga bantuan hukum yang berkembang di Indonesia pada hakikatnya tidak luput dari arus perkembangan bantuan hukum yang terdapat pada negara-negara maju.

Dalam prespektif tertentu, istilah bantuan hukum mempunyai ciri berbeda, yaitu legal aid dan legal assistance. Legal aid diartikan bantuan hukum ditunjukan bagi mereka yang kurang keuangannya dan tidak mampu membayar penasihat hukum. Dari pengertian ini, jelaslah bahwa mereka tidak mampu menyewa jasa penasihat hukum. Legal assistance menjelaskan makna dan tujuan dari bantuan hukum lebih luas dari legal aid. Dalam prespektif legal assistance mengartikan penasihat hukum sebagai ahli hukum, sehingga dalam konteks legal assistance menyediakan jasa bantuan hukum bagi siapa saja tanpa terkecuali. Artinya, ahli hukum memberikan bantuan hukum tidak terbatas pada masyarakat miskin saja, tetapi juga bagi yang mampu membayar prestasi. $^{3}$

${ }^{2}$ Soerjono Soekanto, Bantuan Hukum Suatu Jaminan Tinjauan Sosio Yuridis, (Jakarta: Ghalia Indonesia, 1983), hlm 11.

${ }^{3}$ Bambang Sunggono dan Aries Harianto, Bantuan Hukum dan Hak Asasi Manusia, (Bandung: CV Mandar Maju, 1994), hlm 9. 
Realisasi bantuan hukum dalam konteks legal aid menjadi kenyataan dengan diundangkannya Undang-Undang Nomor 16 Tahun 2011 tentang Bantuan Hukum. Lahirnya Undang-Undang Nomor 16 Tahun 2011 tentang Bantuan Hukum secara nyata diharapkan dapat melindungi hak konstitusional warga negara khususnya yang tidak mampu untuk mendapatkan bantuan hukum.

Lahirnya Undang-Undang Bantuan Hukum tersebut sudah diadvokasi sejak tahun 1998 oleh para aktivis bantuan hukum. Tahun 2004 draft Undang-Undang Bantuan Hukum sudah dibuat, kemudian tahun 2009 masuk ke Program Legislasi Nasional. Barulah pada tanggal 2 November 2011 diundangkan menjadi Undang-Undang Nomor 16 Tahun 2011 tentang Bantuan Hukum. ${ }^{4}$

Konsepsi bantuan hukum dalam Undang Undang Bantuan Hukum Nomor 16 Tahun 2011 merupakan bantuan pembiayaan dari negara bagi masyarakat miskin yang berhadapan dengan hukum. Sebelumnya, negara tidak melakukan pemenuhan hak atas bantuan hukum bagi masyarakat miskin. Justru, peranan tersebut dimulai dan terus dilakukan secara mandiri dan swadaya oleh masyarakat sipil dipelopori YLBHI-LBH (Yayasan Lembaga Bantuan Hukum Indonesia-Lembaga Bantuan Hukum). Kemudian terus berkembang bersama lahirnya organisasi masyarakat sipil lainnya yang bergerak pada bantuan hukum, seperti Perhimpunan Bantuan Hukum dan HAM Indonesia (PBHI), LBH Masyarakat, LBH Apik, LBH Pers, LBH Mawar Saron, LKBH Kampus, Elsam, Kontras, Walhi, dan seterusnya.

Bagi masyarakat miskin, hukum itu menjadi barang mahal dan merasa tidak dijamin oleh hukum. Masyarakat miskin menjadi pengecualian dari hukum, seringkali mendapat perlakukan yang tidak adil. Keadaan ini banyak terjadi negara berkembang dan miskin di dunia.

Hak mendapatkan bantuan hukum semakin dibutuhkan, seiring dinamika pembangunan dan politik yang terjadi di Indonesia. Dinamika tersebut kadangkala memunculkan permasalahan hak dasar manusia yang berujung kepada kriminalisasi terhadap warga negara tertentu. Oleh karena itu, akses mencari keadilan baik di dalam pengadilan maupun di luar pengadilan akan semakin tinggi. Konkritnya, bantuan hukum menjadi tanggung jawab negara dalam rangka memberi akses keadilan bagi warga negara sebagaimana telah diamanahkan UndangUndang Dasar Negara Republik Indonesia Tahun 1945.

Secara teknis untuk mengimplementasikan bantuan hukum bagi masyarakat miskin sebagaimana ditentukan Undang-Undang Nomor 16 Tahun 2011 tentang Bantuan Hukum diatur lebih lanjut dalam Peraturan Pemerintah Nomor 42 Tahun 2013 tentang Syarat dan Tata Cara Pelaksanaan Bantuan Hukum Untuk Masyarakat Miskin. Menurut Peraturan Pemerintah tersebut masyarakat miskin yang membutuhkan bantuan hukum haruslah memiliki surat keterangan tidak mampu dari lurah atau kepala desa. Untuk menyelenggarakan bantuan hukumnya diselenggarakan oleh organisasi bantuan Hukum terakreditasi.

Surat keterangan tidak mampu (disingkat SKTM) tersebut, selain digunakan untuk mendapatkan bantuan hukum juga bisa digunakan untuk keperluan lainnya, seperti

${ }^{4}$ Laporan Tahunan Kementerian Hukum dan HAM RI tanggal 26 Juli 2013, Jakarta. 
bidang pendidikan dan kesehatan. Dalam bidang kesehatan, keluarga miskin bisa mendapatkan perawatan dan pengobatan gratis khususnya bagi mereka yang belum memiliki jaminan kesehatan dalam bentuk apapun. Dalam mendapatkan bantuan hukum di pengadilan, SKTM bisa digunakan oleh pihak yang berperkara untuk meringankan biaya perkara dan memohon kepada negara agar diberikan pendampingan hukum oleh advokat atau lembaga bantuan hukum.

Tetapi, praktik pengunaan SKTM untuk mendapatkan bantuan hukum adakalanya disalahgunakan, seperti yang terjadi di Provinsi Riau. Dalam pengalamatan penulis, masyarakat yang memiliki SKTM meminta bantuan hukum dari Lembaga Bantuan Hukum (LBH), tetapi pada kenyataannya mampu. Hal ini pernah terjadi dalam perkara cerai gugat di Pengadilan Agama Kelas 1 A Pekanbaru, klien yang meminta bantuan hukum ke LBH Fakultas Hukum Universitas Lancang Kuning mengaku tidak mampu, padahal dirinya mampu. ${ }^{5}$

Kewajiban negara yang tertuang dalam peraturan perundangan tentang bantuan hukum. Sebagai sebuah harga demokrasi yang harus dibayar, tentu pelaksanaan bantuan hukum ini harus dikawal oleh semua pihak. Dengan demikian, akses keadilan bagi orang miskin dapat terpenuhi.

Menurut ketua LBH Fakultas Hukum Universitas Lancang Kuning kebijakan pemberian bantuan hukum di Provinsi Riau merujuk pada Peraturan Gubernur Riau Tahun 2016 tentang Bantuan Hukum Untuk Masyarakat Miskin. Tetapi, dalam Peraturan Gubernur Riau Tahun 2016 tersebut tidak menjelaskan kriteria masyarakat miskin yang konkrit, sehingga penggunaan SKTM untuk bantuan hukum bisa tidak tepat sasaran. ${ }^{6}$ Praktik pemberian bantuan hukum yang tidak tepat sasaran perlu dijelaskan melalui penelitian lebih lanjut.

Dalam penelusuran penulis, ada beberapa penelitian yang sudah pernah dilakukan berkaitan dengan konteks bantuan hukum. Penelitian Pujiono, membahas tentang bantuan hukum dalam perspektif tanggung jawab Negara. Siddid Ahmad melakukan penelitian tentang tanggung organisasi advokat dalam memberikan bantuan hukum untuk masyarakat miskin. Tetapi, penelitian sebelumnya itu tidak menyentuh pada teknis penyalahgunaan keadaan tidak mampu untuk mendapatkan bantuan hukum. Oleh karena masalah penyalahgunaan keadaan tidak mampu untuk mendapatkan bantuan hukum belum pernah diteliti maka ada 2 (dua) permasalahan dalam penelitian ini. Pertama, bagaimanakah penyalahgunaan surat keterangan tidak mampu sebagai syarat penerima bantuan hukum secara cuma-cuma bagi masyarakat miskin di Provinsi Riau? Kedua, bagaimana upaya mengatasi penyalahgunaan surat keterangan tidak mampu sebagai syarat penerima bantuan hukum secara cumacuma bagi masyarakat miskin di Provinsi Riau?

Berkaitan dengan permasalahan tersebut maka penelitian ini penting dilakukan karena akan menjelaskan penyalahgunaan SKTM sebagai syarat penerima bantuan hukum secara cuma-cuma bagi masyarakat

\footnotetext{
${ }^{5}$ Wawancara dengan Fahmi selaku Ketua Organisasi Bantuan Hukum Fakultas Hukum Universitas Lancang Kuning pada tanggal 15 April 2016.

6lbid.
} 
miskin di Provinsi Riau. Sejalan dengan itu, tujuan yang hendak dicapai dari penelitian ini, yaitu Pertama, menjelaskan penyalahgunaan surat keterangan tidak mampu sebagai syarat penerima bantuan hukum secara cuma-cuma bagi masyarakat miskin di Provinsi Riau. Kedua, menjelaskan upaya mengatasi penyalahgunaan surat keterangan tidak mampu sebagai syarat penerima bantuan hukum secara cuma-cuma bagi masyarakat miskin di Provinsi Riau.

\section{Metode Penelitian}

\section{Jenis penelitian}

Jenis penelitian ini adalah penelitian hukum sosiologis, dilakukan dengan cara pendekatan empiris dengan cara menelaah perumusan masalah yang hendak diteliti sekaligus memberikan gambaran dan analisis terhadap penyalahgunaan surat keterangan tidak mampu sebagai syarat penerima bantuan hukum secara cuma-cuma bagi masyarakat miskin di Provinsi Riau.

\section{Lokasi penelitian}

Penelitian ini dilakukan di Provinsi Riau, adapun pertimbangan penulis dalam menjatuhkan pilihan terhadap lokasi ini berkaitan dengan fenomena, yakni adanya kecenderungan penyalahgunaan surat keterangan tidak mampu di Provinsi Riau.

\section{Populasi dan sampel}

a. Populasi

Populasi yang terkait dengan penelitian ini diantaranya: Kepala Divisi Yankum Kanwil Kementerian Hukum dan HAM Riau, Kepala Biro Hukum Provinsi Riau dan Organisasi Bantuan Hukum $(\mathrm{OBH})$ yang terakreditasi di Provinsi Riau.

\section{b. Sampel}

Jumlah dari masing-masing populasi di atas sebanyak 1 (satu) orang maka secara sensus keseluruhannya penulis tetapkan menjadi sampel. Keadaan populasi dan sampel penelitian ini dapat dilihat pada tabel berikut:

Tabel

\section{Populasi dan Sampel}

\begin{tabular}{c|lccc}
\hline No. & \multicolumn{1}{|c}{ Populasi } & $\begin{array}{c}\text { Jumlah } \\
\text { Populasi }\end{array}$ & Sampel & $\begin{array}{c}\text { Persentase } \\
(\%)\end{array}$ \\
\hline 1 & $\begin{array}{l}\text { Kepala Divisi Yankum } \\
\text { Kanwil Kementerian } \\
\text { Hukum dan HAM Riau }\end{array}$ & 1 & 1 & 100 \\
2 & $\begin{array}{l}\text { Kepala Biro Hukum } \\
\text { Provinsi Riau }\end{array}$ & 1 & 1 & 100 \\
$\begin{array}{l}\text { Organisasi Bantuan } \\
\text { Hukum (OBH) yang } \\
\text { terakreditasi di Provinsi } \\
\text { Riau }\end{array}$ & 7 & 1 & 14 \\
\hline
\end{tabular}




\section{Sumber data}

a. Data primer

Data primer diperoleh dan dikumpulkan melalui informasi dari sampel secara langsung, mengenai hal-hal terkait dengan masalah yang diteliti.

b. Data sekunder

Data sekunder diperoleh melalui kepustakaan yang bersifat mendukung data primer.

c. Data tertier

Data tertier diperoleh melalui ensiklopedi dan yang sejenisnya yang berfungsi untuk mendukung data primer dan data sekunder.

\section{Teknik pengumpulan data}

a. Observasi

Teknik ini dilakukan dengan cara pengamatan langsung terhadap permasalahan yang diteliti.

b. Wawancara

Wawancara dilakukan secara terstruktur, yaitu tanya jawab antara penulis dengan sampel terikat dengan daftar pertanyaan yang telah disiapkan sesuai dengan arah permasalahan yang diteliti.

c. Kajian kepustakaan

Metode pengumpulan data ini dilakukan melalui peran aktif penulis untuk membaca kepustakaan yang memiliki korelasi dengan permasalahan yang diteliti.

\section{Pembahasan}

Penyalahgunaan Surat Keterangan Tidak Mampu Sebagai Syarat Penerima Bantuan Hukum Secara Cuma-Cuma Bagi Masyarakat Miskin di Provinsi Riau

Bantuan hukum merupakan hak konstitusional setiap warga sebagai akses keadilan sebagaimana diamanahkan oleh Undang-Undang Dasar Negara Republik Indonesia Tahun 1945. Sesuai praktik internasional, ada 5 (lima) pilar mengenai bantuan hukum:

1. Accesible, bantuan hukum harus dapat diakses dengan mudah.

2. Affordability, bantuan hukum dibiayai oleh negara.

3. Sustainable, bantuan hukum harus terus ada dan tidak tergantung pada donor sehingga negara harus menganggarkannya dalam Anggaran Pendapatan dan Belanja Negara (APBN).

4. Credibility, bantuan hukum harus dapat dipercaya dan memberikan keyakinan bahwa yang diberikan adalah dalam rangka peradilan yang tidak memihak (juga saat mereka menghadapi kasus melawan negara, tidak ada keraguan tentang itu).

5. Accountability, pemberi bantuan hukum harus dapat memberikan pertanggungjawaban keuangan kepada badan pusat dan kemudian badan pusat harus mempertanggungjawabkan kepada parlemen.

Dalam Undang-Undang Nomor 16 Tahun 2011 tentang Bantuan Hukum dikatakan bahwa pemberi bantuan hukum adalah lembaga bantuan hukum atau organisasi kemasyarakatan yang memberi layanan bantuan hukum. Jasa hukum yang diberikan kepada penerima bantuan hukum cuma-cuma, dalam arti mereka tidak mendapat upah dari pihak yang dibantunya, namun pemerintah akan memberikan dana bantuan untuk setiap kasus yang ditangani yang besarnya disesuaikan dengan jenis kasusnya. Dana bantuan tersebut memang tidak akan diberikan kepada semua $\mathrm{OBH}$, tetapi hanya kepada $\mathrm{OBH}$ yang sudah 
memenuhi syarat sesuai dengan UndangUndang Bantuan Hukum. ${ }^{7}$

Dengan demikian, pelaksanaan bantuan hukum di Indonesia diselenggarakan oleh $\mathrm{OBH}$ yang terdaftar dan terakreditasi. Untuk melaksanakan pendaftaran dan akreditasi diberikan kewenangan pada Kementerian Hukum dan HAM Republik Indonesia melalui oleh Kantor Wilayah di provinsi setempat.

Hasil verifikasi/akreditasi organisasi bantuan hukum yang dilakukan oleh Kementerian Hukum dan HAM hasilnya terbagi dalam kategori A, B dan C. Berdasarkan Keputusan Menteri Hukum dan Hak Asasi Manusia Republik Indonesia Nomor M.HH01.HN.03.03 Tahun 2016 tentang Organisasi/ Lembaga Bantuan Hukum yang lulus verifikasi dan akreditasi periode tahun 2016-2018 di Provinsi Riau, terdiri dari:

1. LBH Fakultas Hukum Universitas Lancang Kuning berkedudukan di Kota Pekanbaru.

2. LBH Mahatva berkedudukan di Kota Pekanbaru.

3. LBH Ananda berkedudukan di Kabupaten Rokan Hilir.

4. LBH YLBHI Pekanbaru berkedudukan di Kabupaten Rokan Hilir.

5. LBH KBH Riau berkedudukan di Kota Pekanbaru.

6. LBH Paham Riau berkedudukan di Kota Pekanbaru.

7. LBH Forum Masyarakat Madani Indonesia berkedudukan di Kota Pekanbaru.
Prosedur memperoleh bantuan hukum harus berpedoman pada Peraturan Pemerintah Nomor 42 Tahun 2013 tentang Syarat dan Tata Cara Pelaksanaan Bantuan Hukum Untuk Masyarakat Miskin. Menurut ketentuannya, calon pemohon bantuan hukum (masyarakat miskin) terlebih dahulu membuat permohonan tertulis yang ditujukan kepada ketua $\mathrm{OBH}$ dengan melampirkan SKTM yang dikeluarkan oleh lurah/kepala desa, foto copy Kartu Tanda Penduduk (KTP), dan Kartu Keluarga (KK).

Selanjutnya, dalam waktu 3 hari $\mathrm{OBH}$ harus memberitahukan pada penerima bantuan hukum tentang kesediaan memberikan bantuan hukum secara cuma-cuma. Oleh karena itu, seluruh biaya jasa advokat akan ditanggung oleh negara. Apabila permohonan diterima maka ketua $\mathrm{OBH}$ menunjuk advokat untuk mendampingi atau mewakili penerima bantuan hukum dan dilanjutkan dengan penandatanganan surat kuasa khusus layaknya seorang advokat dengan klien. Penerima bantuan hukum akan terus didampingi atau diwakili sampai perkara selesai. $^{8}$

Sebagaimana telah disinggung SKTM menjadi bagian dari syarat yang diharus dilampirkan dalam mengajukan permohonan bantuan hukum. Standar operasional prosedur layanan untuk mendapatkan SKTM yang biasa diterapkan di kelurahan atau desa: Pertama, masyarakat yang memperoleh SKTM faktanya harus keluarga tidak mampu. Selain itu, alamat yang tertera di KTP harus sesuai dengan domisili keluarga yang bersangkutan. Untuk mendapatkan SKTM, keluarga miskin harus

${ }^{7}$ Mosgan Situmorang, Membangun Akuntabilitas Organisasi Bantuan Hukum, Jurnal Recthsvinding Media Pembinaan Hukum Nasional, Volume 2, Nomor 1, April 2013, hlm. 107.

${ }^{8}$ Wawancara dengan Helen dari Divisi Pelayanan Hukum Kantor Wilayah Riau Kementerian Hukum dan Hak Asasi Manusia pada tanggal 15 Maret 2017 jam 15.00 Wib. 
menyiapkan KK asli dan foto copy serta KTP asli dan foto copy. Dokumen tersebut dibawa ke Ketua Rukun Tetangga (RT) untuk meminta surat pengantar tidak mampu. Kemudian, surat pengantar dari RT beserta foto copy KTP dan KK tersebut dibawa ke kantor lurah atau desa.

Pihak RT sampai dengan lurah/kepala desa tersebut dalam mengeluarkan SKTM dapat berpedoman dengan kriteria miskin menurut standar Badan Pusat Statistik (BPS). Lembaga tersebut mendefinisikan kemiskinan berdasarkan besaran pengeluaran per orang dalam per harinya. Dalam konteks itu, pengangguran dan rendahnya penghasilan menjadi pertimbangan untuk penentuan kriteria tersebut. Ada 14 kriteria miskin menurut BPS dan dari 14 kriteria tersebut minimal kriteria 9 terpenuhi maka suatu rumah tangga dapat dikatakan miskin. Adapun kriterianya sebagai berikut: ${ }^{9}$

1. Luas lantai bangunan tempat tinggal kurang dari $8 \mathrm{~m}^{2}$ per orang.

2. Jenis lantai tempat tinggal terbuat dari tanah/bambu/kayu murahan.

3. Jenis dinding tempat tinggal dari bambu/rumbia/kayu berkualitas rendah/tembok tanpa diplester.

4. Tidak memiliki fasilitas buang air besar/ bersama-sama dengan rumah tangga lain.

5. Sumber penerangan rumah tangga tidak menggunakan listrik.

6. Sumber air minum berasal dari sumur/ mata air tidak terlindung/ sungai/ air hujan.
7. Bahan bakar untuk memasak seharihari adalah kayu bakar/ arang/minyak tanah.

8. Hanya mengkonsumsi daging/susu/ ayam dalam satu kali seminggu.

9. Hanya membeli satu stel pakaian baru dalam setahun.

10. Hanya sanggup menyediakan makan sebanyak satu/dua kali dalam sehari.

11. Tidak sanggup membayar biaya pengobatan di puskesmas/ poliklinik.

12. Sumber penghasilan kepala rumah tangga adalah petani dengan luas lahan $500 \mathrm{~m}^{2}$, buruh tani, nelayan, buruh bangunan, buruh perkebunan dan atau pekerjaan lainnya dengan pendapatan di bawah Rp 600.000,00 (enam ratus ribu) per bulan.

13. Pendidikan tertinggi kepala rumah tangga tidak sekolah/tidak tamat sekolah dasar (SD) / tamat SD.

14. Tidak memiliki tabungan/barang yang mudah dijual dengan minimal $\mathrm{Rp}$ 500.000,00 (lima ratus ribu rupiah), seperti sepeda motor kredit/non kredit, emas, ternak, kapal motor, atau barang modal lainnya.

Setelah memperoleh SKTM dari lurah atau kepala desa, surat tersebut bisa dibawa ke lembaga bantuan hukum yang dituju. Ketika berperkara, SKTM bisa dibawa ke organisasi bantuan hukum untuk mendapatkan bantuan hukum secara cuma-cuma dan memohon kepada negara untuk meringankan biaya perkara atau gratis. ${ }^{10}$

\footnotetext{
${ }^{9} \mathrm{http}: / /$ keluargaharapan.com/14-kriteria-miskin-menurut-standar-bps/ di akses tanggal 23 Agustus 2017 jam 09.45 Wib.

10Wawancara dengan Fahmi selaku Ketua Organisasi Bantuan Hukum Fakultas Hukum Universitas Lancang Kuning pada tanggal 21 April 2017 jam 10.00 Wib di Pekanbaru.
} 
Fasilitas yang didapat penerima bantuan hukum, yaitu diberikan pendampingan hukum oleh advokat yang tergabung dalam $\mathrm{OBH}$ sampai perkara selesai. Meskipun tanpa OBH sebenarnya advokat diwajibkan memberikan bantuan hukum bagi orang atau kelompok miskin dalam mewujudkan prinsip-prinsip negara hukum. Namun, kewajiban advokat dalam memberikan bantuan hukum cumacuma terdapat banyak kendala dalam praktiknya. Oleh karena itu, menurut Ade Irawan Taufik diperlukan campur tangan negara. Permasalahannya belum ada konsepsi bantuan hukum itu dan sinergisitas arah bantuan hukum yang berpihak pada masyarakat miskin dan sinergisitas peran negara dan advokat dalam pemberian bantuan hukum cuma-cuma bagi orang atau kelompok miskin. ${ }^{11}$

Bantuan hukum bukanlah semata-mata pro bono publico work, tetapi merupakan suatu kewajiban advokat (duty or obligation). Orang miskin berhak memperoleh pembelaan dari advokat atau pembela umum yang bekerja untuk organisasi bantuan hukum. Sebagai pengakuan hak individu (individual right), prinsip persamaan dihadapan hukum (equality befor the law) dijamin dalam sistem hukum Indonesia. Persamaan ini tidak mengenal pengecualian. ${ }^{12}$ Tetapi, kewajiban advokat dalam bantuan sebagaimana telah dikemukakan terdapat banyak kendala yang menyebabkan kewajiban tersebut tidak berjalan maksimal.

Solusi tidak maksimalnya kewajiban advokat dalam memberikan bantuan hukum maka Undang-Undang Nomor 16 Tahun 2011 tentang Bantuan Hukum memberikan jalan keluar, sehingga penerima bantuan hukum juga mendapatkan fasilitas pembebasan dari biaya perkara dari negara. Atas fasilitas bantuan hukum yang diberikan oleh pemerintah maka bisa terjadi kecenderungan penyalahgunaan SKTM. Dari hasil wawancara penulis tentang penyalahgunaan SKTM sebagai syarat penerima bantuan hukum secara cuma-cuma bagi masyarakat miskin di Provinsi Riau faktanya telah terjadi. Fakta itu diketahui ketika pemohon bantuan hukum yang bernama Soviana Betty datang ke $\mathrm{OBH}$, yaitu LBH Fakultas Hukum Universitas Lancang Kuning membawa SKTM dari kelurahan. Pemohon akan berperkara di Pengadilan Agama Kelas 1 A Pekanbaru. Selanjutnya, OBH melakukan verifikasi permohonan. Dari hasil verifikasi maka LBH Fakultas Hukum Universitas Lancang Kuning menolak memberikan bantuan hukum secara cuma-cuma karena pemohon dianggap mampu. Setelah ditelusuri, ternyata Soviana Betty tersebut mampu mengkuliahkan anak di tempat yang mahal dan memiliki sejumlah harta. Setelah ditolak, pemohon yang sebelumnya datang membawa SKTM kemudian dalam berperkara ternyata mampu membayar jasa advokat.

Aditya selaku ketua organisasi bantuan hukum LBH Pekanbaru, dalam wawancara mengemukakan "pemohon bantuan hukum yang datang ada kalanya tidak seperti orang miskin, mereka memakai kendaraan pribadi, memakai hand phone mahal, memakai perhiasan emas, dan baju mahal. Hal ini juga dibenarkan oleh ibu Winda sebagai staf pelaksana pos layanan hukum di Pengadilan

${ }^{11}$ Ade Irawan Taufik, Sinergisitas Peran dan Tanggung Jawab Advokat dan Negara Dalam Pemberian Bantuan Hukum Cuma-Cuma, Jurnal Recthsvinding Media Pembinaan Hukum Nasional, Volume 2, Nomor 1, April 2013, hlm. 47.

${ }^{12}$ Iwan Setyawan dan Adawiyah Nasution, Proses Pemberian Bantuan Hukum Secara Prodeo Terhadap Pelaku Tindak Pidana Oleh Advokat, Jurnal Kultura, Volume 15 Nomor 1, September 2014, hlm. 4404. 
Agama Pekanbaru, ketika berperkara perceraian pemohon meminta pembagian harta dari suami". ${ }^{13}$

Nyta Salina salah seorang penerima bantuan hukum dari organisasi bantuan hukum mengatakan "untuk mengurus SKTM tidak sulit apabila persyaratan lengkap maka akan diberikan, karena ketua RT dan RW juga tidak terlalu mempersoalkan kriteria masyarakat miskin". ${ }^{14}$ Meskipun sudah ada standar operasional prosedur layanan untuk mendapatkan SKTM sebagaimana telah disinggung, kelemahannya diawali dari pengantar RT yang tidak selektif.

Dari informasi ini maka dalam praktik penerima bantuan hukum bisa tidak tepat sasaran dikarenakan cara mendapatkan SKTM yang tidak selektif dan penyalahgunaan SKTM itu sendiri, sementara SKTM itulah yang menjadi syarat untuk mendapatkan bantuan hukum.

Meskipun Pemerintah Provinsi Riau sudah membuat Peraturan Daerah (Perda) Nomor 3 Tahun 2015 tentang Bantuan Hukum Untuk Masyarakat Miskin, namun Perda tersebut tidak menjelaskan teknis mengurus SKTM yang nantinya dijadikan syarat mendapatkan bantuan hukum. Perda tersebut merupakan amanat dari Undang-Undang Bantuan Hukum yang memberi ruang bagi daerah untuk mengalokasikan dana penyelenggaraan bantuan hukum dalam Anggaran Pendapatan dan Belanja Daerah (APBD). Apabila daerah berkehendak mengalokasikan dana bantuan hukum dalam APBD maka pemerintah daerah dan DPRD harus mengaturnya dalam Perda. ${ }^{15}$ Perda Provinsi Riau tersebut secara khusus sudah menjamin terlaksananya hak konstitusional khususnya bagi orang atau kelompok orang miskin dalam mendapatkan akses bantuan hukum. Untuk memaksimalkan akses tersebut dalam waktu dekat akan diterbitkan Peraturan Gubernur (Pergub) Riau tentang Syarat dan Tata Cara Pemberian Bantuan Hukum Untuk Masyarakat Miskin. Sementara Pergub itu belum ada maka regulasi teknis tentang kriteria masyarakan miskin yang berhak mendapatkan bantuan hukum tidak ada pedomannya. Oleh karena itu, praktik penyalahgunaan SKTM sebagai syarat untuk mendapatkan bantuan hukum secara cuma-cuma bagi masyarakat miskin di Provinsi Riau akan tetap terjadi.

\section{Upaya Mengatasi Penyalahgunaan Surat Keterangan Tidak Mampu Sebagai Syarat Penerima Bantuan Hukum Secara Cuma- Cuma Bagi Masyarakat Miskin di Provinsi Riau}

Bantuan hukum merupakan salah satu upaya mengisi hak asasi manusia (HAM) terutama bagi lapisan masyarakat termiskin rakyat Indonesia. Bantuan hukum harus dimaknai dan dilaksanakan sebagai upaya perjuangan menegakkan HAM bagi si miskin. Semestinya tujuan bantuan hukum perlu diperluas, karena tidak saja terbatas pada bantuan hukum individual, tetapi juga struktural

\footnotetext{
${ }^{13}$ Wawancara dengan Winda sebagai staf pelaksana pos layanan hukum di Pengadilan Agama Pekanbaru pada tanggal 25 Mei 2017

${ }^{14}$ Wawancara dengan Nyta Salina salah seorang penerima bantuan hukum dari organisasi bantuan hukum LBH Fakultas Hukum Universitas Lancang Kuning pada tanggal 10 Mei 2017.

${ }^{15}$ Eka N.A.M. Sihombing, Mendorong Pembentukan Peraturan Daerah Tentang Bantuan Hukum di Provinsi Sumatera Utara, Jurnal Recthsvinding Media Pembinaan Hukum Nasional, Volume 2, Nomor 1, April 2013, hlm. 81.
} 
dan juga jangan terbelenggu dengan jalur-jalur formal semata. Undang-Undang Nomor 16 Tahun 2011 tentang Bantuan Hukum belum komprehensif menjangkau konteks komunal atau masyarakat secara kolektif, sehingga perlu dipikirkan pula SKTM yang bersifat kolektif. ${ }^{16}$

Berdasarkan Pasal 4 Ayat (2) dan 3 Undang-Undang Nomor 16 Tahun 2011, ditentukan bahwa bantuan hukum yang diberikan oleh pemberi bantuan hukum kepada penerima bantuan hukum meliputi masalah hukum keperdataan, pidana, dan tata usaha negara, baik litigasi maupun non-litigasi. Bantuan hukum tersebut meliputi menjalankan kuasa, mendampingi, mewakili, membela, dan/ atau melakukan tindakan hukum lain untuk kepentingan hukum penerima bantuan hukum. Kesemua bentuk bantuan hukum tersebut diberikan secara cuma-cuma bagi warga miskin yang dapat menunjukkan SKTM. ${ }^{17}$

Pembahasan terdahulu telah dijelaskan penyalahgunaan SKTM sebagai syarat untuk mendapatkan bantuan hukum secara cumacuma bagi masyarakat miskin di Provinsi Riau. Praktik tersebut akan tetap terjadi sepanjang cara mendapatkan SKTM yang tidak selektif dan penyalahgunaan SKTM itu sendiri. Selama praktik tersebut terjadi maka program bantuan hukum gratis bisa tidak tepat sasaran. Untuk itu, diperlukan pengawasan agar program bantuan hukum cuma-cuma bisa tepat sasaran. ${ }^{18}$ Menurut Thalis Noor Cahyadi penyelenggaraan bantuan hukum harus ditunjang oleh aturan main yang jelas yang tidak membuka tafsir liar sehingga membuat potensi adanya pemberian bantuan hukum yang salah sasaran. ${ }^{19}$

Dari penelitian ini terungkap untuk mendapatkan SKTM jika persyaratan lengkap maka akan diberikan pengantar dari RT. Hal tersebut dijelaskan Nyta Salina dalam wawancara dengan penulis yang mengatakan "untuk mengurus SKTM tidak sulit apabila persyaratan lengkap maka akan diberikan, karena ketua RT dan RW juga tidak terlalu mempersoalkan kriteria masyarakat miskin". ${ }^{20}$ Dari informasi ini maka cara mendapatkan SKTM tidak ketat dan selektif sehingga membuka celah penyalahgunaan.

Terkait tidak ketat dan selektifnya cara untuk mendapatkan SKTM tersebut menimbulkan pertanyaan bagaimana menverifikasi keadaan miskin yang sesungguhnya, sementara pemegang STKM belum tentu miskin? Tentunya, akan menjadi kendala tersendiri pihak $\mathrm{OBH}$ dalam memverifikasi permohonan bantuan hukum.

Bagi pihak $\mathrm{OBH}$ jika syarat mendapatkan bantuan hukum secara formal hanya

${ }^{16}$ Ihdi Karim Makinara, Pengaruh Bantuan Hukum Terhadap Masyarakat Miskin (Meninjau UndangUndang Nomor 16 Tahun 2011 tentang Bantuan Hukum), Jurnal Recthsvinding Media Pembinaan Hukum Nasional, Volume 2, Nomor 1, April 2013, hlm. 1.

${ }^{17}$ Chyntia Wirawan, Implementasi Pemberian Bantuan Hukum Cuma-Cuma (Pro Bono Publico) Dalam Perkara Pidana di Kota Medan Ditinjau Berdasarkan Undang-Undang Nomor 16 Tahun 2011 tentang Bantuan Hukum (Studi di Lembaga Bantuan Hukum Medan), Jurnal Mahupiki, Volume 2, Nomor 1, Tahun 2014, hlm. 286.

${ }^{18} \mathrm{https}: / /$ nasional.sindonews.com/read/746284/13/program-bantuan-hukum-diharapkan-tepat-sasaran1370360804 diakses tanggal 20 Agustus 2017 jam 23.00 Wib.

${ }^{19}$ Thalis Noor Cahyadi, Efektifitas Pos Bantuan Hukum di Pengadilan (Studi Pada Posbakum Pengadilan Agama Sleman Tahun 2011-2012), Jurnal Recthsvinding Media Pembinaan Hukum Nasional, Volume 2, Nomor 1, April 2013, hlm. 17.

${ }^{20}$ Wawancara Nyta Salina salah seorang penerima bantuan hukum dari organisasi bantuan hukum LBH Fakultas Hukum Universitas Lancang Kuning pada tanggal 10 Mei 2017. 
berdasarkan SKTM, sementara SKTM itu tidak selektif atau mudah didapat maka hak mendapatkan bantuan hukum sejatinya hak orang miskin, tapi justru dinikmati orang kaya. Selama belum ada syarat dan kriteria yang jelas menentukan kriteria miskin maka bagi OBH akan sulit menentukan kriteria miskin. Jika tidak ada solusinya maka siapa saja yang mengajukan permohonan bantuan hukum membawa SKTM maka secara formal sudah dianggap miskin. Terhadap fenomena ini, perlu solusi atau upaya sehingga penyalahgunaan SKTM sebagai syarat penerima bantuan hukum secara cuma-cuma bagi masyarakat miskin di Provinsi Riau dapat diatasi.

Menurut panitia pengawas daerah upaya yang harus dilakukan panitia pengawas daerah harus segera menyusun regulasi persyaratan materil menentukan kriteria miskin yang berhak memperoleh bantuan hukum secara cumacuma dari negara. Kemudian mensosialisasikannya kepada seluruh pemerintahan kota/ kabupaten di Provinsi Riau supaya bisa diteruskan ke kelurahan/desa sampai ke tingkat RT. Panitia Pengawas Daerah sendiri terdiri dari Divisi Pelayanan Hukum Kanwilkumham Riau dan Biro Hukum Provinsi Riau.

Sebelum ada regulasi materil tersebut, setidaknya dapat menggunakan kriteria miskin yang ditentukan BPS. Kriteria tersebut telah dijelaskan pada pembahasan terdahulu. Kalau dikaitkan kriteria miskin BPS tersebut dengan keadaan pemohon bantuan hukum faktanya tidak sesuai dengan kriteria tersebut. Hasil survey ke penulis ke Pos Layanan Hukum di Pengadilan Agama Pekanbaru pada tanggal 22 Agutus 2017 dijumpai fakta pemohon dan penerima bantuan hukum tidak sesuai kriteria miskin, padahal yang bersangkutan mengajukan bantuan hukum cuma-cuma dengan membawa SKTM. Bila dikaitkan kriteria pendidikan, pemohon bantuan hukum cuma-cuma itu ada yang tamat SMA dan ada yang diploma. Kemudian tentang pakaian, pemohon atau penerima bantuan hukum menggunakan pakaian yang bagus, memiliki alat komunikasi handphone bahkan android.

Sementara belum ada regulasi materil kriteria miskin maka kriteria miskin yang ditentukan BPS dapat jadikan pedoman dalam melakukan verifikasi pemohon bantuan hukum cuma-cuma. Untuk itu, upaya yang dapat dilakukan Pemerintah dalam hal ini Divisi Pelayanan Hukum Kanwikumham Riau dan Pengawas Daerah Biro Hukum Provinsi Riau mensosialisasikan kriteria miskin BPS tersebut kepada OBH di Provinsi Riau. Kemudian juga mensosialisasikan kriteria tersebut kepada kelurahan/desa di Provinsi Riau sehingga dapat dijadikan pedoman dalam menerbitkan SKTM.

\section{Kesimpulan}

1. Penyalahgunaan SKTM sebagai syarat penerima bantuan hukum secara cumacuma di Provinsi Riau dapat terjadi, karena cara mendapatkan SKTM tidak selektif. Sementara SKTM merupakan syarat formal untuk mendapatkan bantuan hukum tersebut. Sementara sampai saat ini belum ada regulasi untuk menentukan kriteria miskin yang dapat dipedomani dalam menerbitkan SKTM. Meskipun BPS telah membuat kriteria keluarga miskin, tetapi kriteria tersebut bukan produk hukum sehingga tidak mempunyai kekuatan mengikat untuk ditaati.

2. Upaya mengatasi penyalahgunaan SKTM sebagai syarat penerima bantuan hukum secara cuma-cuma bagi masyarakat miskin di Provinsi Riau harus dilakukan oleh panitia pengawas daerah. Sementara 
belum ada regulasi materil kriteria miskin maka kriteria miskin yang ditentukan BPS dapat jadikan pedoman dalam melakukan verifikasi pemohon bantuan hukum cumacuma. Untuk itu, upaya yang dapat dilakukan pengawas daerah mensosialisasikan kriteria miskin BPS tersebut kepada OBH di Provinsi Riau. Kemudian juga mensosialisasikan kriteria tersebut kepada kelurahan/desa di Provinsi Riau sehingga dapat dijadikan pedoman dalam menerbitkan SKTM.

\section{Saran}

1. Kepada Pemerintah Provinsi Riau, Pengawas Daerah Kanwilkumham Riau dan $\mathrm{OBH}$ sebaiknya membuat regulasi yang mempunyai kekuatan mengikat dalam menerbitkan SKTM yang akan dipergunakan untuk mendapatkan bantuan hukum cuma-cuma.

2. Pemerintah Provinsi Riau harus mendorong terbentuknya $\mathrm{OBH}$ baru karena idealnya ada $5 \mathrm{OBH}$ dalam setiap kabupaten/kota, supaya program bantuan hukum dapat dilaksanakan secara merata seluruh wilayah Provinsi Riau.

\section{Referensi}

Ade Irawan Taufik. Sinergisitas Peran dan Tanggung Jawab Advokat dan Negara Dalam Pemberian Bantuan Hukum Cuma-Cuma, Jurnal Recthsvinding Media Pembinaan Hukum Nasional. Volume 2. Nomor 1. April 2013.

Bambang Sunggono dan Aries Harianto. 1994.

Bantuan Hukum dan Hak Asasi Manusia. Bandung: CV Mandar Maju.

Chyntia Wirawan. Implementasi Pemberian

Bantuan Hukum Cuma-Cuma (Pro Bono

Publico) Dalam Perkara Pidana di Kota
Medan Ditinjau Berdasarkan UndangUndang Nomor 16 Tahun 2011 tentang Bantuan Hukum (Studi di Lembaga Bantuan Hukum Medan). Jurnal Mahupiki. Volume 2. Nomor 1. Tahun 2014.

Eka N.A.M. Sihombing. Mendorong Pembentukan Peraturan Daerah Tentang Bantuan Hukum di Provinsi Sumatera Utara. Jurnal Recthsvinding Media Pembinaan Hukum Nasional. Volume 2. Nomor 1. April 2013.

Eka Susylawati. Implementasi Perkara Prodeo Bagi Masyarakat Miskin di Pengadilan Agama Pamekasan. Jurnal Nuansa, Volume 10. Nomor 1 Januari-Juni 2013. Ihdi Karim Makinara. Pengaruh Bantuan Hukum Terhadap Masyarakat Miskin (Meninjau Undang-Undang Nomor 16 Tahun 2011 tentang Bantuan Hukum). Jurnal Recthsvinding Media Pembinaan Hukum Nasional. Volume 2. Nomor 1. April 2013.

Iwan Setyawan dan Adawiyah Nasution. Proses

Pemberian Bantuan Hukum Secara

Prodeo/Terhadap Pelaku Tindak Pidana

Oleh Advokat. Jurnal Kultura. Volume 15.

Nomor 1 September 2014.

Mosgan Situmorang. Membangun Akuntabilitas

Organisasi Bantuan Hukum, Jurnal

Recthsvinding Media Pembinaan

Hukum Nasional. Volume 2. Nomor 1. April 2013.

Soerjono Soekanto. 1983. Bantuan Hukum Suatu Jaminan Tinjauan Sosio Yuridis. Jakarta: Ghalia Indonesia.

Thalis Noor Cahyadi, Efektifitas Pos Bantuan Hukum di Pengadilan (Studi Pada Posbakum Pengadilan Agama Sleman Tahun 2011-2012). Jurnal Recthsvinding Media Pembinaan Hukum Nasional. Volume 2. Nomor 1. April 2013. 